Revista de Metalurgia 51(3)

July-September 2015, e047

ISSN-L: 0034-8570

doi: http://dx.doi.org/10.3989/revmetalm.047

\title{
Low friction coefficient coatings Ni-Cr by magnetron sputtering, DC
}

\author{
Jorge Morales-Hernández ${ }^{\mathrm{a}, \bowtie}$, Araceli Mandujano-Ruíz ${ }^{\mathrm{a}}$, Julieta Torres-González ${ }^{\mathrm{a}}$, \\ Francisco J. Espinoza-Beltrán ${ }^{b}$, Héctor Herrera-Hernández ${ }^{c}$ \\ ${ }^{a}$ Centro de Investigación y Desarrollo Tecnológico en Electroquímica, S.C., Parque \\ Tecnológico Querétaro s/n, Sanfandila, CP 76703, Querétaro, México \\ ${ }^{b}$ Centro de Investigación y de Estudios Avanzados del IPN (Unidad Querétaro), Libramiento \\ Norponiente 2000, Fracc. Real de Juriquilla, CP 76230, Querétaro, México \\ 'Universidad Autónoma del Estado de México, Ing. Industrial, Boulevard Universitario s/n, \\ Predio San Javier Atizapán de Zaragoza, Estado de México, México \\ Corresponding author: jmorales@cideteq.mx
}

Submitted: 10 July 2014; Accepted: 18 May 2015; Available On-line:

\begin{abstract}
Magnetron Sputter Deposition technique with DC was used for the deposition of Ni-Cr coatings on AISI 316 SS like substrate. The cathode with a nominal composition Ni-22 at $\% \mathrm{Cr}$ was prepared by Mechanical Alloying (MA) technique, with a maximum milling time of 16 hours and, with a high energy SPEX 8000 mill. The coatings were made under Argon atmosphere at room temperature with a power of $100 \mathrm{~W}$ at different times of growth. Chemical composition, microstructure, topography, nanohardness and wear of the coatings were evaluated using the techniques of microanalysis by energy dispersive X-ray analyzer (EDAX), X-Ray Diffraction (XRD), Atomic Force Microscopy (AFM), Nano-indentation and pin-on-Disk, respectively. After milling, was not detected contamination in the mixtures. XRD analysis revealed that the microstructure of the Ni-Cr alloy was maintained in the coatings with respect to MA powders, with some degree of recrystallization. Nanohardness values were in the order of $8.8 \mathrm{GPa}$ with a Young's modulus of $195 \mathrm{GPa}$. The adhesion of the films was evaluated according to their resistance to fracture when these were indented at different loads using Vickers microhardness. The wear test results showed a decrease in the friction coefficient with respect to the increase of thickness' films, getting a minimum value of 0.08 with a thickness of $1 \mu \mathrm{m}$ and which correspond with the maximum growing time.
\end{abstract}

KEYWORDS: Mechanical alloying (MA); Magnetron sputtering; Ni-Cr coatings

Citation / Cómo citar este artículo: Morales-Hernández, J., Mandujano-Ruíz, A., Torres-González, J., EspinozaBeltrán, F.J., Herrera-Hernández, H. (2015) "Low friction coefficient coatings Ni-Cr by magnetron sputtering, DC" Rev. Metal. 51(3): e047. doi: http://dx.doi.org/10.3989/revmetalm.047.

RESUMEN: Recubrimientos Ni-Cr con bajo coeficiente de fricción depositados por magnetron sputtering, DC. La técnica de Deposición por Chisporroteo Magnético (Magnetron Sputtering) con el proceso DC, fue usado para la deposición de los recubrimientos de Ni-Cr sobre acero inoxidable AISI 316 como sustrato. El cátodo con una composición nominal Ni-22 at \% Cr fue preparado por la técnica de Aleado Mecánico (AM), con un tiempo máximo de molienda de 16 horas y con un molino de alta energía tipo SPEX 8000. Las películas se realizaron bajo una atmósfera de argón a temperatura ambiente con una potencia de $100 \mathrm{~W}$ a diferentes tiempos de crecimiento. La composición química, microestructura, topografía, nanodureza y abrasión de los recubrimientos fueron evaluados usando las técnicas de microanálisis por Energía Dispersa de Rayos-X (EDX), Difracción de Rayos-X (DRX), Microscopia de Fuerza Atómica (AFM), Nano-indentación y Pin-on-Disk, respectivamente. Después de molienda, no se detectó contaminación en las mezclas. Los análisis por DRX revelan que la microestructura de la aleación $\mathrm{Ni}-\mathrm{Cr}$ se mantiene en los recubrimientos con respecto a los polvos $\mathrm{AM}$, con ciertos 
grados de recristalización. Los valores de Nanodureza fueron del orden de 8,8 GPa con un módulo de Young de $195 \mathrm{GPa}$. La adhesión de las películas fue evaluada de acuerdo con su resistencia a la fractura al ser indentadas a diferentes cargas con microdureza Vickers. Los resultados de las pruebas de abrasión muestran una disminución en el coeficiente de fricción con respecto al incremento en el espesor de la película, obteniendo un valor mínimo de 0,08 con un espesor de $1 \mu \mathrm{m}$ y que corresponde al máximo tiempo de crecimiento.

PALABRAS CLAVE: Aleado mecánico (AM); Deposición por Chisporroteo Magnético; Recubrimientos Ni-Cr

Copyright: (C) 2015 CSIC. This is an open-access article distributed under the terms of the Creative Commons Attribution-Non Commercial (by-nc) Spain 3.0 License.

\section{INTRODUCTION}

Corrosion and wear are the main failure mechanisms that affect performance, security and integrity of materials. Globally, this problem has been tried to control through the use of different industrial coatings. One of the industries that have serious problems of corrosion-erosion due to the nature of their processes is observed in the oil industry by the use of acidic and basic conditions at different pressures and temperatures. This kind of process typically use materials such as stainless steel and super alloys like Monel, recognized for their resistance to wear and corrosion, with some limitations under extreme conditions, resulting in considerable economic losses due line stoppages with health risks and the ambient. The combined effect of wear and corrosion constitutes $5 \%$ of failure causes of the operational infrastructure of the processes in the industrial sector, so that is at fifth place like the further important degradation mechanisms in terms of cost per premature failure (Bermúdez et al., 2003). Tribological systems that operate in corrosive environments are identified like "tribo-corrosive" systems where the loss of material takes place simultaneously as a result of wear and corrosion (Mischler et al., 1999).

High temperature corrosion coatings have been developed through the deposition of the coatings in the solid state like Chemical Vapor Deposition (CVD), Physical Vapor Deposition (PVD) and Thermal Spray like High Velocity Oxy-Fuel (HVOF), which have been incorporated successfully to the industry, with a wide acceptance to provide solutions to many tribocorrosive problems, besides being environmentally friendly, without altering the mechanical or structural characteristics from the substrate (Agüero, 2007).

Physical vapor deposition process (often just called thin film processes) is atomistic deposition process in which material is vaporized usually from a solid source in the form of atoms or molecules and transported in the form of vapor to the substrate. Physical vapor deposition process can be use to deposit films of elements and alloys as well as compounds (Bunshah, 2001). The main categories of PVD processing are vacuum deposition (evaporation), arc vapor deposition, ion plating and sputter deposition used in this job. Physical sputtering is a non-thermal vaporization process where surface atoms are physically ejected from a solid surface by a momentum transfer from an atomic-sized energetic bombarding particles, which is usually a gaseous ion, accelerated from a low pressure plasma $(<5$ mTorr) where the sputtered particles suffer few or no gas phase collisions in the space between the target and the substrate (Mattox, 2010).

$\mathrm{Ni}-\mathrm{Cr}$ coatings have been widely used in hot corrosion protection for boiler tubes in power stations (Ou et al., 2008). In this paper the alloy $\mathrm{Ni}-22$ at $\%$ $\mathrm{Cr}$ was synthesized by mechanical alloying (MA) from elemental powders of nickel and chromium and compacted to the manufacture of $50.8 \mathrm{~mm}$ (2") cathode and used for the subsequent deposition by the magnetron sputtering technique on a stainless steel 316 like substrate for their tribology evaluation. The wear behaviors of Ni-Cr nanocomposite coatings as a function of the $\mathrm{Cr}$ content was studied by Zhou et al. (2010), during the codeposition of $\mathrm{Ni}$ and micrometer sized $\mathrm{Cr}$ particles by electrodeposition techniques were the minimum friction coefficient obtained was 0.2 with better wear resistance than the pure Ni coating (Zhou et al., 2010). The codeposition of Ni-Cr composite coatings shows a better wear resistance compared with the as-deposited pure Ni coating, due to the incorporation of nanometer $\mathrm{Cr}$ particles in the deposit, that reduce the size of Ni crystals (grain refinement), with the subsequent increase of hardness and wear resistance (Zhao et al., 2009).

\section{EXPERIMENTAL METHOD}

The mixture $\mathrm{Ni}-22$ at $\% \mathrm{Cr}$ was mechanically alloyed in a high energy SPEX 8000 mill; the starting elements were nickel with a particle size of $83 \mu \mathrm{m}$ (purity $>99 \%$ Merck \& Alfa) and chromium with a particle size of $71 \mu \mathrm{m}$ (purity $>98 \%$, Spectrum). The weight ratio of steel balls and powders (balls / load) was 6:1, with a total weight of the mixture of $8 \mathrm{~g}$. Milling was performed under an argon atmosphere for intervals of 4 hours until complete a maximum milling time of 16 hours. The alloyed powders were characterized at each interval by X-ray diffraction in a Rigaku diffractometer D2100, in the range of 20 to 100 in $2 \theta$ degrees using cobalt radiation (Cok $\alpha)$ with $\lambda=1.78899 \AA$, with a voltage of $30 \mathrm{kV}$ and a current of $16 \mathrm{~mA}$. The size, morphology and composition of 
the powders at different milling intervals were characterized with a scanning electron microscope (SEM) model XL30 Philips brand-5 with a microprobe of $\mathrm{X}$-ray, EDAX. Coatings of Ni-Cr system were prepared by magnetron sputtering technique, using an Intercovamex DC sputtering system, model V3. Targets of $5.08 \mathrm{~mm} \mathrm{(2")} \mathrm{in} \mathrm{diameter} \mathrm{from} \mathrm{the} \mathrm{mix-}$ ture $\mathrm{Ni}-22$ at $\%$ Cr obtained by MA were compacted under uniaxial pressure of $90 \mathrm{t}$. The coatings were deposited on stainless steel 316 substrates at room temperature, varying the times of growth (1,2 and 3 hours), identifying the samples like M1. M2 and M4 respectively. The power for the deposition was $100 \mathrm{~W}$ with $22 \mathrm{Amp}$ and with a continuous flow of argon of $50 \mathrm{~cm}^{3} \mathrm{~min}^{-1}$ for all growths. The distance between the target and substrate was $50 \mathrm{~mm}$ with a working pressure of $1 \times 10^{-3}$ mbar. Atomic force microscope (AFM) NanoScope IV Digital Instruments, was used to obtain topographic images to determine the roughness of the coatings. Hysintron Indenter was used with a Bercovich diamond tip; nanoidentación tests were conducted at different loads in the range of 600 to $9000 \mu \mathrm{N}$. In each run were taken $4 \times 4$ indentations. The hardness and elastic modulus were calculated using the Oliver and Pharr method. Finally, was used a Tribometer CSM Instruments with the pin-on-disk technique to perform wear tests according the standard ASTM G99-05 (2010).

\section{RESULTS AND DISCUSSION}

\subsection{Mechanical Alloying of Powders}

Figure 1 shows the XRD patterns of the mixture as a function of milling time. In the first $4 \mathrm{~h}$ of MA the relative intensity of the peaks of nickel decreases while the characteristic peaks of chromium tend to disappear. At 8,12 and 16 hours of milling are still observed a decrease in the intensity of the nickel peaks, with a slight widening and the complete disappearance of the Cr peaks. During the MA, a large deformation is induced within the particles and this is manifested in the generation of crystalline defects such as dislocations, vacancies, stacking faults and, with an increase in the number of grain boundaries. The presence of these structural defects increases the diffusivity of solute element in the matrix, thus achieving an increase in the solubility of chromium into the nickel above the levels established in the equilibrium diagrams (ASM Handbook, 2002). To know the evolution of the alloy in function of time, the grain size value was calculated from measuring the average width of the diffraction peak of nickel (110) and using the Scherrer equation without considering the effect of deformation. By increasing the grinding time, grain size tends to decrease until a value of $10 \mathrm{~nm}$ at 16 hours of milling, so we can speak of a homogeneous nanostructured solid solution of chromium in nickel $\mathrm{Ni}(\mathrm{Cr})$.

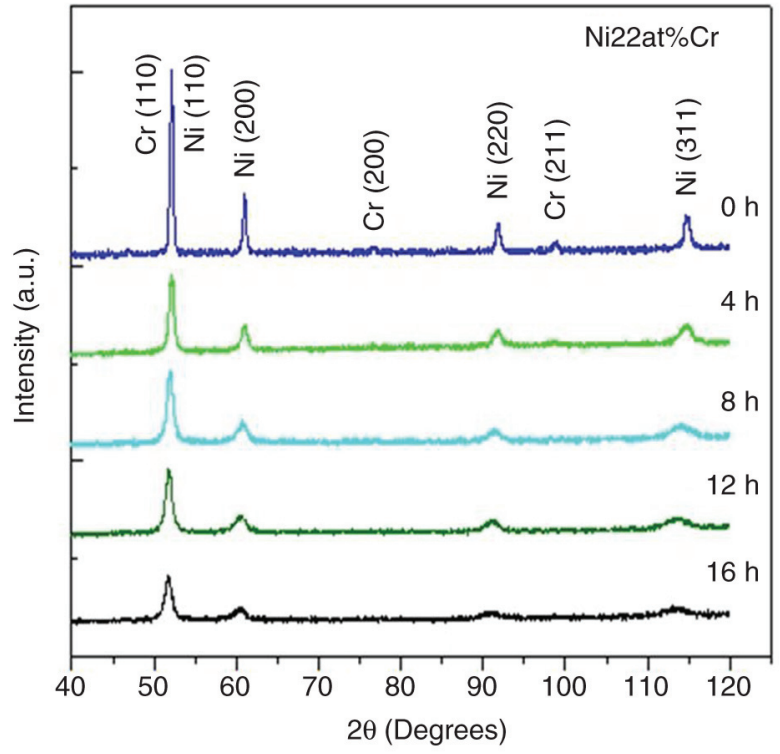

FIGURE 1. Diffraction patterns of mixture $\mathrm{Ni}-22$ at $\% \mathrm{Cr}$ at different milling time.

In order to know the morphology and powders size after the milling process, were obtained micrographs by SEM (Fig. 2). The original powders showed flakes of different sizes for chromium and conglomerates for the nickel. The morphology in the first four hours of milling shows the conglomerate morphology of the nickel powders completely lost, showing a tendency to form large spherical particles and laminated between 4 and 8 hours of MA as is shown in Fig. $2 b$ and Fig. 2c. After 12 hours of milling (Fig. 2c) the particles retain the lamellar morphology but fail to show a tendency to grow. Finally at 16 hours of milling are observed flakes of different sizes with a distribution of particle size in the mixture in the order of 20 to $120 \mu \mathrm{m}$. It is hoped that with increased milling time, the particles tend to fracture as a result of hardening mechanisms by deformation and by the formation of a solid solution of chromium in nickel. The fine particle size represented a constraint for the compaction of the powders during the cathode manufacture used for the vaporization process, because fine powders become incompressible at room temperature, in addition to fragile features of the powders obtained at the maximum milling time.

\subsection{Ni-Cr Coatings by PVD}

Figure 3 shows the $\mathrm{X}$-ray diffraction patterns of Ni-Cr film as a function of growing time. We can see that the solid solution of chromium in nickel obtained in the MA powders is conserved on the films with some recristallization and, without observing structural changes between the films in function of deposition time. Micrographs at the 

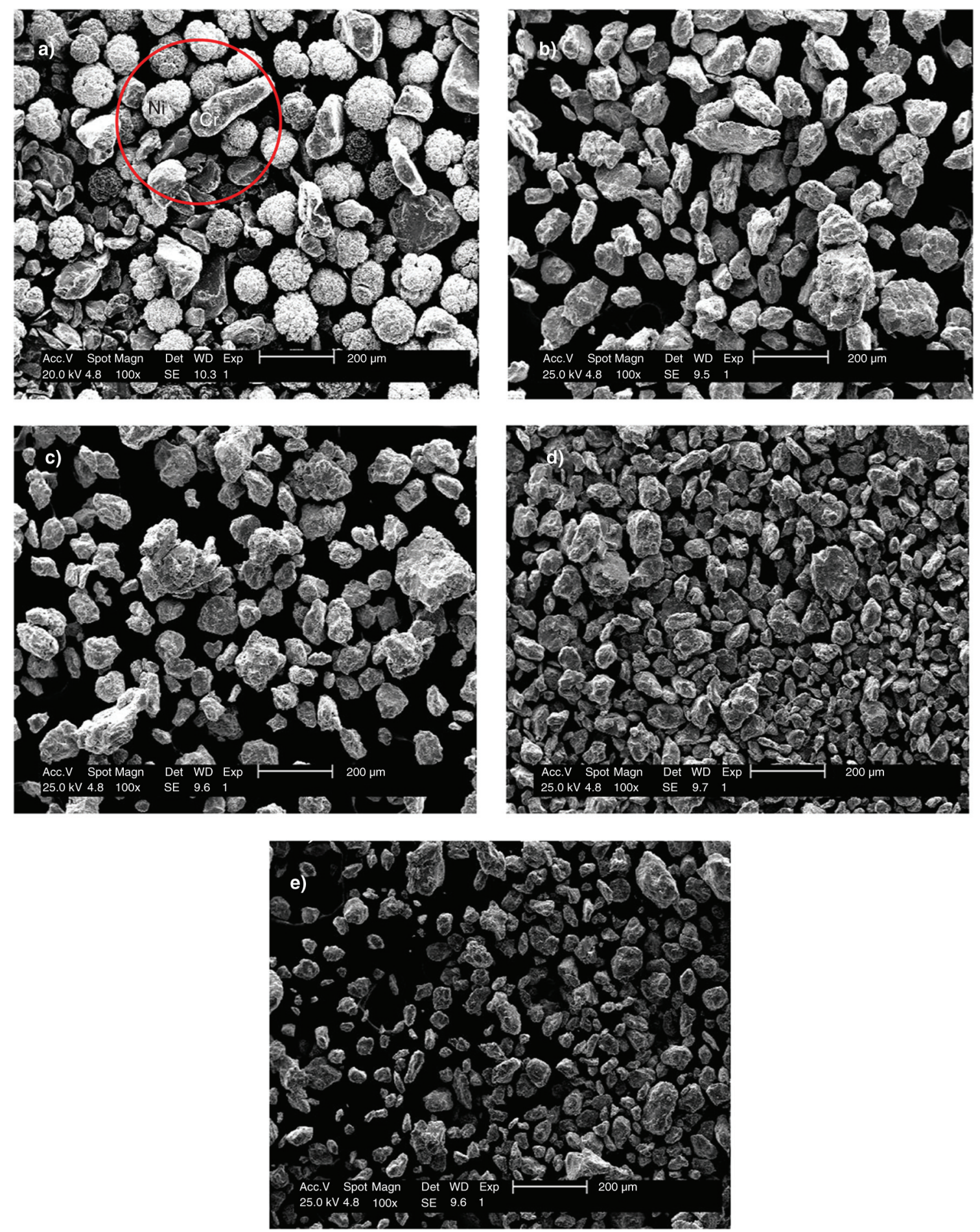

Figure 2. Morphology of the powders of the alloy Ni-22 at $\%$ Cr to different milling times: a) 0 hours, b) 4 hours, c) 8 hours, d) 12 hours and e) 16 hours.

surface films corresponding with 1,2 and 3 hours of growing time, shows similar surface conditions as is reported in Fig. 4. The images show that the film is composed of small particle clusters with an average size less than $0.3 \mu \mathrm{m}$. Is not observed porosity or precipitation on the film, corresponding with homogeneous films.

Coatings thickness was taken from the cross section and measure by SEM. Table 1 report the average coatings thickness, obtained as a function of growing 


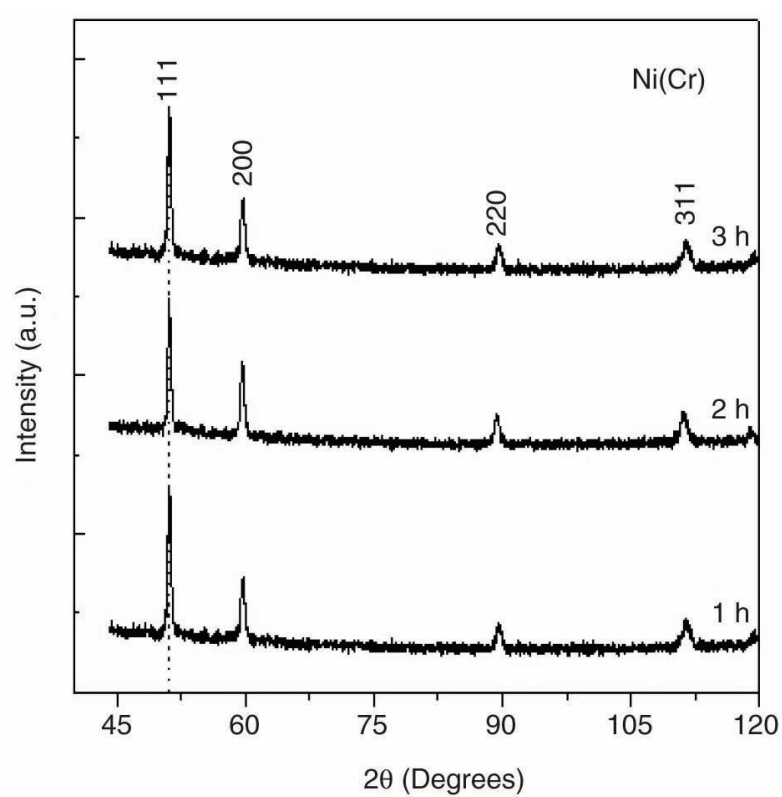

FIGURE 3. XRD patterns of $\mathrm{Ni}-22$ at $\%$ $\mathrm{Cr}$ films at different growth time.

time for each sample, including the film that was obtained using commercial powder like reference with the same composition, observing correlation between the growing time and thickness obtained in the coatings.

Results of microanalysis carried out in different samples not reported contamination such as iron or carbon from the vial and grinding media, although there are small traces of oxygen that can correspond with a slight oxidation at the surface films. The composition of the films is very close to the ground product, so that the stoichiometry in the cathodes obtained by MA $(\mathrm{Ni}-22$ at $\% \mathrm{Cr})$ is preserved in the vaporizing process.

Nanoindentation test was carried out in each sample through several cycles of loading in the range of $600-9000 \mu \mathrm{N}$, obtaining a $4 \times 4$ matrix with 16 tracks as is show in the Fig. 5; using the software Hysitron Tribo View was determined the roughness, obtaining the maximum value of $12.25 \mathrm{~nm}$ in the sample M3 with $1 \mu \mathrm{m}$ of thickness. Each value of Load vs. Depth of penetration was graphed to calculate hardness and modulus of elasticity according to the model of Oliver and Pharr (Oliver and Pharr, 1992). Values reported in Table 2 are consistent with respect the thickness film. More process time for this system means a more homogeneous deposition and more compact coating, where were obtained the maximum hardness of 8.0 and $8.8 \mathrm{GPa}$ for $\mathrm{M} 3$ and commercial sample respectively due to the deposition of the solid solution of chromium in nickel $\mathrm{Ni}(\mathrm{Cr})$; results that are highest than the obtained in the codeposition of nanocomposites of $\mathrm{Ni}-\mathrm{Cr}$ synthesized by electrochemical methods (Zhou et al., 2010). a)

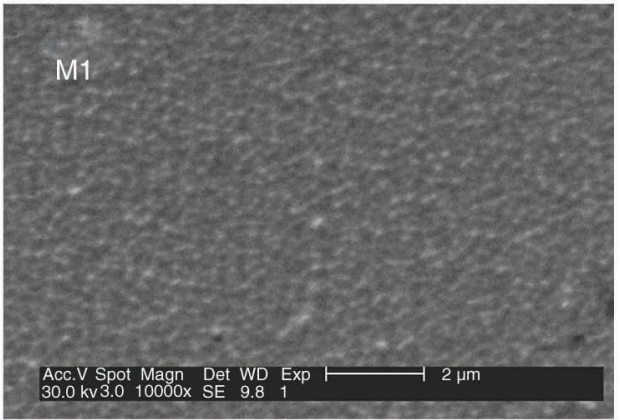

b)

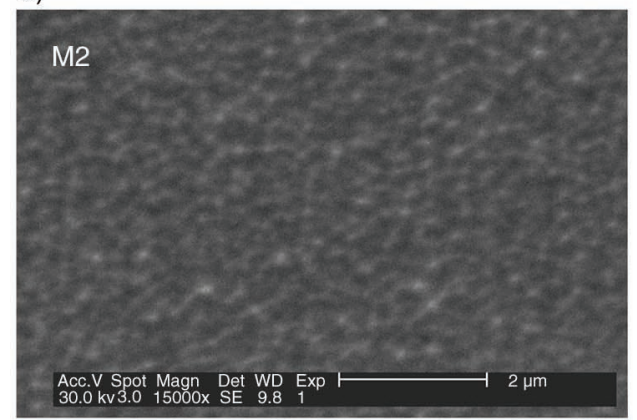

c)

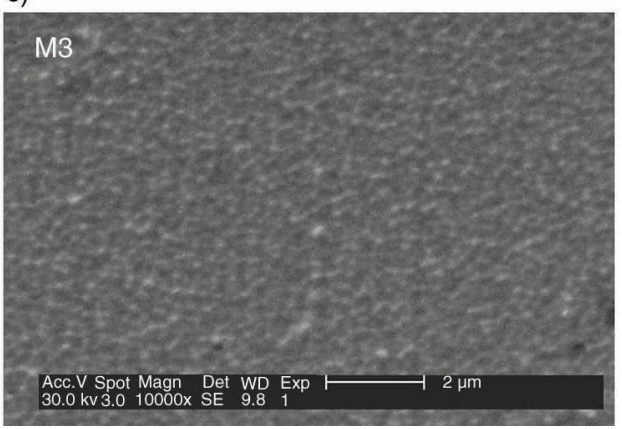

FIGURE 4. Micrographs by scanning electron microscopy at the surface of films for different growing time:

a) 1 hour, b) 2 hours and c) 3 hours.

The adhesion of the films was characterized by the Vickers indentation test to evaluate the effect of the load with the possible release of material along the contour of the fingerprint. In all samples there was not observed the formation of cracks at the border of the indentation so that the coating exhibits good adhesion on the substrate.

TABLE 1. Deposited film thickness as a function of growth time

\begin{tabular}{lcc}
\hline Sample classification & Deposit time $(\mathbf{h})$ & Film thickness $(\boldsymbol{\mu m})$ \\
\hline M1 & 1 & 0.32 \\
M2 & 2 & 0.80 \\
M3 & 3 & 1.00 \\
Commercial & 3 & 1.00 \\
\hline
\end{tabular}



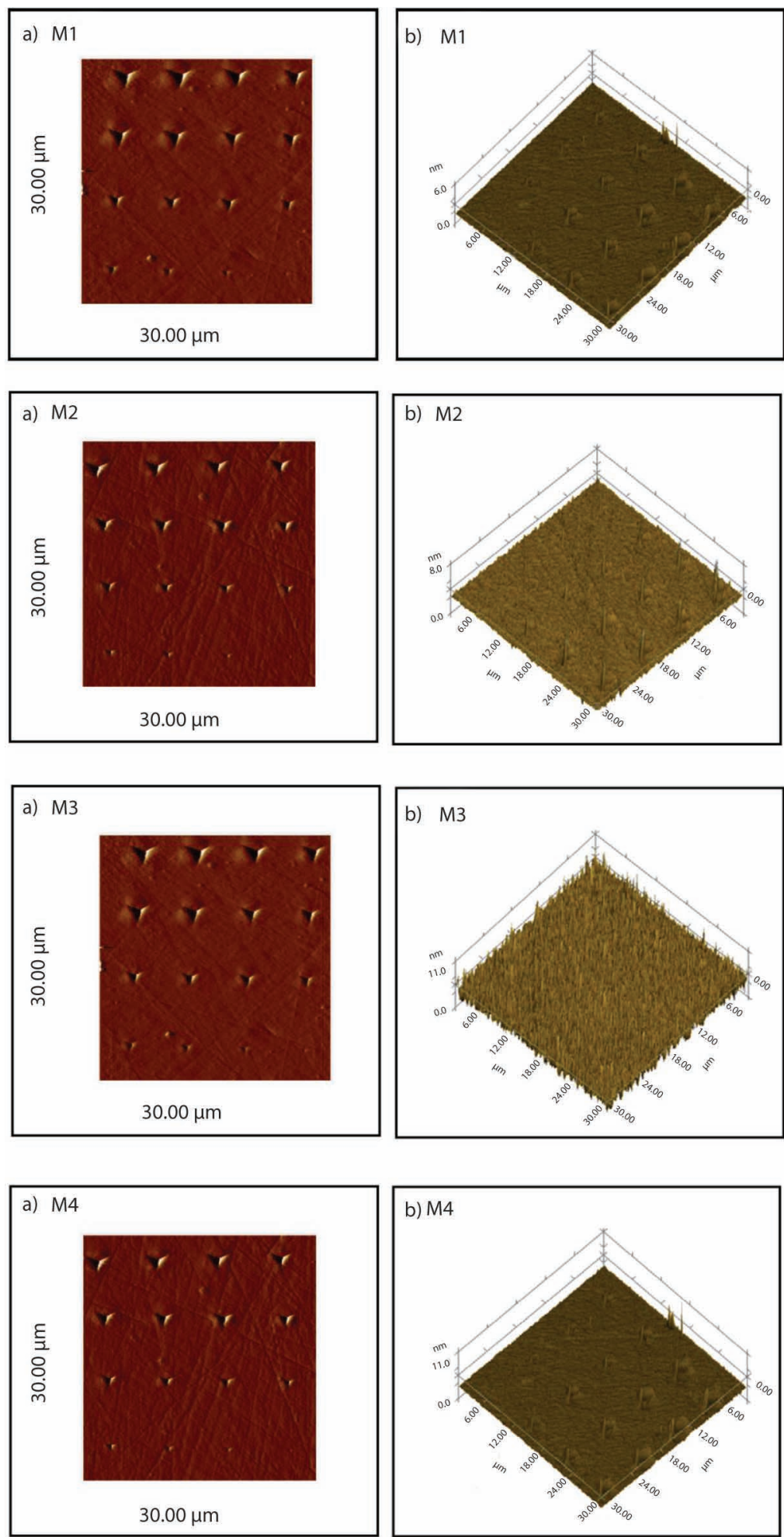

Figure 5. Nanoindentation test through several cycles of loading in the range of $600-9000 \mu \mathrm{N}$, to obtain a $4 \times 4$ matrix.

Friction coefficient was calculated as a function of sliding distance (range) for each sample, reported for SS316 like substrate the value of 1.05 with a footprint width of $506 \mu \mathrm{m}$. Sample M3 reported the minimum friction coefficient that was 0.087 with a footprint width of $392 \mu \mathrm{m}$ (Fig. 6), value that is 
TABLE 2. Hardness and elastic modulus calculated

\begin{tabular}{lccc}
\hline $\begin{array}{l}\text { Sample } \\
\text { classification }\end{array}$ & $\begin{array}{c}\text { Film } \\
\text { Thickness }(\boldsymbol{\mu m})\end{array}$ & $\begin{array}{c}\text { Hardness } \\
(\mathbf{G P a})\end{array}$ & $\begin{array}{c}\text { Young module } \\
(\mathbf{G P a})\end{array}$ \\
\hline M1 & 0.32 & 4.5 & 127 \\
M2 & 0.80 & 5.2 & 195 \\
M3 & 1.00 & 8.0 & 195 \\
Commercial & 1.00 & 8.8 & 193 \\
\hline
\end{tabular}

lowest than others reported by electrodeposition (Zhou et al., 2010). Table 3 shows the results of the trial Pin-on disk where we can observe how the friction coefficient tends to decrease with increasing thickness of the coating, getting the sample M3 with the lowest friction coefficient which is very similar to Teflon (0.05-0.1).

\section{CONCLUSIONS}

- The stoichiometry and microstructure of the alloy $\mathrm{Ni}-20$ at $\%$ Cr obtained by MA were preserved during the deposition of the coatings by the PVD technique, where is consistent the deposition of a solid solution of chromium in nickel $\mathrm{Ni}(\mathrm{Cr})$ with a crystal size in the order of nanometers $(10 \mathrm{~nm})$ and with a positive influence in
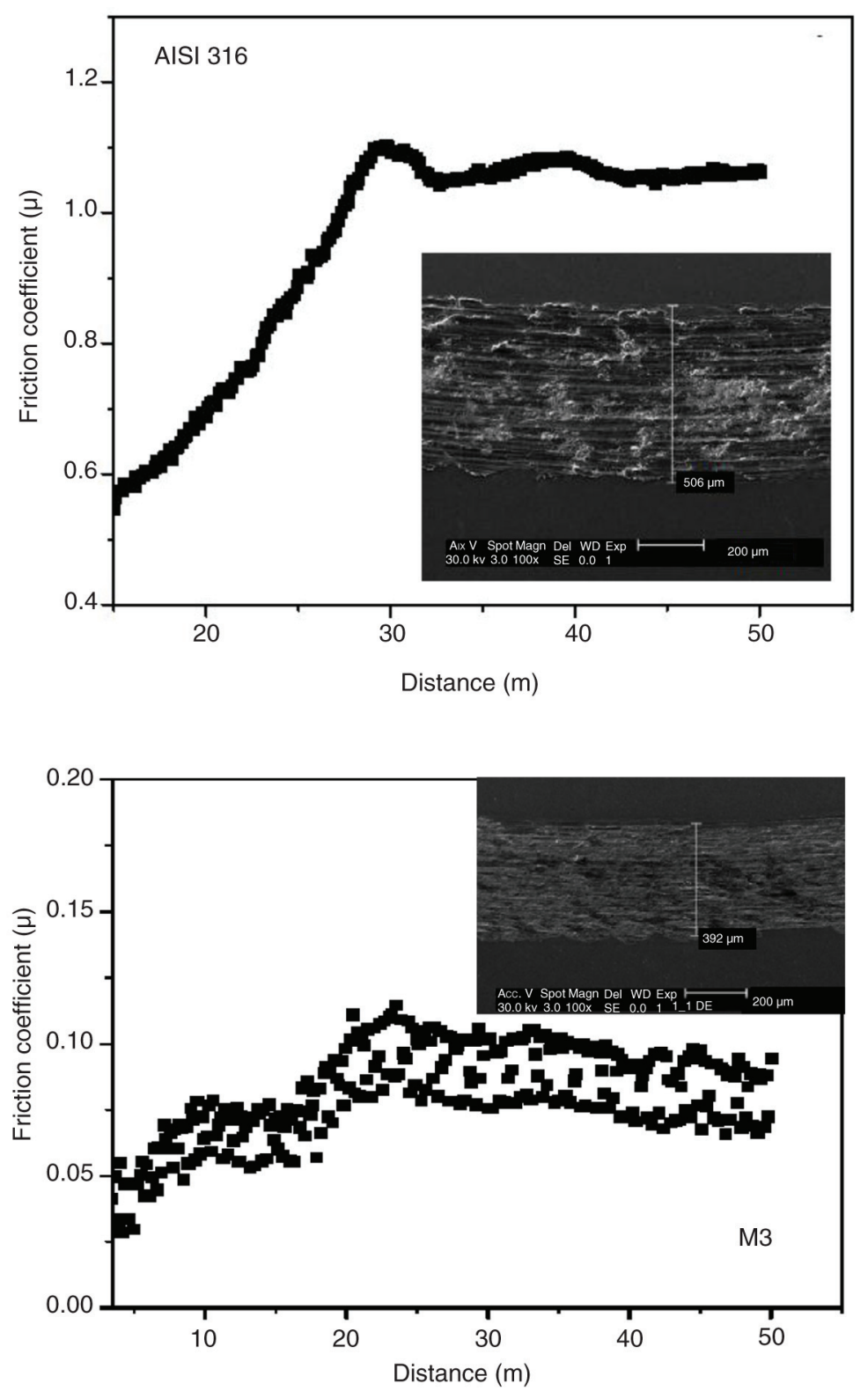

FIgURE 6. Trace of wear and friction coefficient vs. the distance of travel for the stainless steel 316 and the sample M3 (3 hours). 
TABLE 3. Wear results in the coating $\mathrm{Ni}-22$ at $\% \mathrm{Cr}$

\begin{tabular}{lcc}
\hline Sample classification & Friction coefficient & Trace width $(\boldsymbol{\mu m})$ \\
\hline Substrate AISI 316 & 1.050 & 506 \\
M1 & 0.800 & 413 \\
M2 & 0.120 & 489 \\
M3 & 0.087 & 392 \\
Commercial & 0.270 & 443 \\
\hline
\end{tabular}

their mechanical properties like hardness, Young module and wear resistance, this last one associate with the low friction coefficient reported.

- Friction coefficient was directly proportional with the coating thickness until get a minimum value of 0.087 as similar as the Teflon, corresponding in the sample with a thickness of $1 \mu \mathrm{m}$.

- Coatings Ni-20 at $\%$ Cr obtained from elemental powders mechanically alloyed and deposited by the PVD technique to the appropriate thickness, offer a good lubricant coating with high mechanical properties (hardness $8.8 \mathrm{GPa}$ and Young module $164 \mathrm{GPa}$ ) due to their low friction coefficient and crystal size in the order of nanometers with respect to the deposition of similar coatings by electrochemical techniques.

\section{ACKNOWLEDGEMENTS}

Author's thanks the financial support provided by the National Council of Science and Technology (CONACyT), with the number project 135100 from basics science program, and the support offered by CINVESTAV-QRO, México, specially to the Dr. F.J. Espinoza Beltrán.

\section{REFERENCES}

Agüero, A. (2007). Recubrimientos contra la corrosión a alta temperatura para componentes de turbinas de gas. Rev. Metal. 43 (5), 384-398. http://dx.doi.org/10.3989/revmetalm.2007. v43.i5.

ASTM G99-05 (2010). Standard Test Method for Wear Testing with a Pin-on-Disc Apparatus, ASTM International.

ASM Handbook (2002). Alloy Phase Diagrams, Vol. 3, ASM International, Materials Park, OH, p. 155.

Bermúdez, M.D., Carrión, F.J., Ginés Martínez, N. (2003). Erosión-corrosión de tantalio, titanio y aceros inoxidables, IX Congreso de Ciencia y Tecnología de Materiales, Madrid, España.

Bunshah, R.F. (2001). Handbook of Hard Coatings, Chapters 2 and 3, Published William Andrew.

Mattox, D.M. (2010). Handbook of Physical Vapor Deposition (PVD) Processing, Chapter 1, Second Edition, Elsevier

Mischler, S., Spiegel, A., Landolt, D. (1999). The role of passive oxide films on the degradation of steel in tribocorrosion systems. Wear 225-229, 1078-1087. http://dx.doi.org/10. 1016/S0043-1648(99)00056-3.

Oliver, W.C., Pharr, G.M. (1992). An improved technique for determining hardness and elastic modulus using load and displacement sensing indentation experiments. J. Mater. Res. 7 (6), 1564-1583. http://dx.doi.org/10.1557/JMR.1992.1564.

Ou, X.-M., Sun, Z., Sun, M., Zou, D.-L. (2008). Hot-corrosion mechanism of $\mathrm{Ni}-\mathrm{Cr}$ coatings at $650{ }^{\circ} \mathrm{C}$ under different simulated corrosion conditions. J. China Univ. Mining \& Technol. 18 (3), 444 448. http://dx.doi.org/10.1016/S10061266(08)60092-9.

Zhao, G.-G., Zhou, Y.-B., Zhang, H.-J. (2009). Sliding wear behaviors of electrodeposited Ni composites coatings containing micrometer and nanometer $\mathrm{Cr}$ particles. T. Nonferr. Metal. Soc. China 19 (2), 319-323. http://dx.doi.org/10.1016/ S1003-6326(08)60271-X.

Zhou, Y.-B., Zhao, G.-G., Zhang, H.-J. (2010). Fabrication and wear properties of co-deposited $\mathrm{Ni}$-Cr nanocomposite coatings. T. Nonferr. Metal. Soc. China 20 (1), 104-109. http://dx.doi.org/10.1016/S1003-6326(09)60104-7. 